ljtihad: Jurnal Wacana Hukum Islam dan Kemanusiaan

Vol. 19, No. 2 (2019), pp. 147-167 doi : 10.18326/ijtihad.v19i2.147-167

\title{
Contribution of islamic law in the discretionary scheme that has Implications for corruption
}

\author{
Muhammad Chairul Huda, Budi Ispriyarso \\ Universitas Diponegoro Semarang \\ E-mail:muhammadchairulbuda@student.undip.ac.id, budiispriyarso@ymail.com \\ DOI: 10.18326/ijtihad.v19i2.147-167
}

This paper explores the studies of the contribution of the Islamic law to discretion (freis ermessen) that has implications for corruption. This used a normative juridical study method, where the law was seen as a normative tool with a library research approach. The exploration of the Islamic law is carried out because it is one of the material sources of law in Indonesia. This paper aims to provide solutions to the discretion products which are the products and actions of state administrative officials (bestuurshandeling) so as not to be trapped in corruption. There are two findings of this study. First, the making of the discretionary scheme to identify the problems to be resolved in discretionary actions that have implications for corruption results in the basic values that have not been interpreted to the practical level and personality problems. Second, the contribution of Islamic law to this discretion problem lies in the basic values that can be used as a reference to the practical level by referring to the ushul principles contained in the literature of the Islamic law and the personality, in which the officials must perform the exemplary attitudes, muroqobah, qona'ab and protecting themselves and their families from bad things, so that the abuse of power in discretion does not lead to corruption.

Tulisan ini mengeksplorasi kajian tentang kontribusi hukum Islam terhadap diskresi (freis ermessen) yang berimplikasi pada tindak pidana korupsi. Penelitian ini menggunakan metode studi yuridis normatif, di mana hukum dipandang sebagai alat normatif dengan pendekatan penelitian kepustakaan. Penggalian hukum Islam yang dilakukan ini karena hukum Islam merupakan salah satu sumber materiil hukum di Indonesia. Tujuan penulisan ini adalah memberikan solusi atas produk diskresi yang merupakan tindakan pejabat administrasi negara (bestuurshandeling) agar tidak terjebak pada tindak pidana korupsi. Kajian ini menghasilkan temuan, pertama pembuatan skema diskresi untuk mengindentifikasi permasalahan apa yang perlu diselesaikan dalam tindakan diskresi yang berimplikasi pada korupsi. Hasilnya ada pada nilai dasar yang belum terinterprestasikan hingga dalam 
tataran praktis dan permasalahan personality. Kedua, kontribusi hukum Islam terhadap permasalahan diskresi ini terletak pada nilai dasar hukum Islam yang kemudian dapat dijadikan acuan hingga tataran praktis. Mengacu pada kaidah-kaidah Ushul yang terdapat dalam literasi hukum Islam, maka terdapat keharusan bagi pejabat untuk memiliki sifat keteladanan, muroqobah, qona'ah dan menjaga diri dan keluarga dari hal-hal buruk agar penyalahgunaan kekuasaan yang dimiliki dalam hal diskresi tidak berujung pada tindak pidana korupsi.

Keywords: Discretion; abuse of power; Islamic law

\section{Introduction}

Indonesia is a state of law (rechtstaat) as stated in Article 1 paragraph (3) of the 1945 Constitution of the Republic of Indonesia. This can be interpreted that everything in the government, including the behavior of the people, is based on prevailing laws and regulations, so Indonesia is not only a power-based country (machstaat) ansich, but also a country based on agreed legal norms. Rechstaat, in the study of the administrative law or State Administrative Law (HAN), underlines that every policy of the government and state administrators both at the central and regional levels must be in accordance with and based on the prevailing law. The function of $\mathrm{HAN}$ is as a regulator as well as a means of fighting for/ protecting the public interest from any forms of irregularities committed by the state officials and administrative officials in order to realize the ideals of the state, namely creating an orderly, just, prosperous and peaceful society (welfare state).

The function of the universality of law is to maintain the order in a social structure. More specifically in the context of HAN, Sjachran Basah explains 4 (four) functions of the law. The first is the directive function to direct and shape the society as aspired in the purpose of the state life in accordance with the 1945 constitution of the Republic of Indonesia. The second function is integrative to keep and preserve the balance, harmony, and suitability of the community and state life. The third function is perspective, which is the improvement of the behaviors of the public administration officials and the public. The fourth is the corrective function to make corrections to the behaviors of public administration officials from the public in the event of a dispute over rights and obligations to obtain justice (Basah, 1992: 13).

Satjipto Rahardjo (2010: 65) said that the law, interpreted as a scriptualistic and textual regulation in the legislation, was often left behind by the reality of the dynamics and 
development of society. The law -including HAN- often "stutters" in catching up with current changes or cases. In the fiqhiyyah theorem, it is stated that "la yunkaru taghayyur alahkām bi tagayyur al-az̧minah wa al-amkinah wa al-ahwäl" (Subhi, 1981: 220) (indisputably, the changes of the law are due to the changes of times, places and social situations). Therefore, the law must not stagnate. It must always synergize with the space and time that continues to grow.

The problem is what if there is an urgent need, but the law/legislation does not yet regulate it, while services to the community must continue. Because of the left-behind nature of the law, the state administrative law (HAN) regulates the discretionary power (freise ermessen) in the form of initiatives for public services in efforts to provide services (Githa, 2017: 4). The discretionary authority is regulated by the Law No. 30 of 2014 concerning Government Administration for public services to perform their duties and obligations as appropriate. Discretion aims at the corridors of the benefit of the community in general to eliminate bottlenecks in services. Discretion is not in the context of deviations from that authority. In the Islamic law studies in general, the obligation of leaders is tasaruf al-imam alà ra'iyyah manütun bi al-maslạ̧ah, which means that the actions and policies of a leader over his/her people must be based on their benefits.

The problem that often arises from the granting of discretionary authority is the frequent abuse of power committed by public officials in the interests of individuals and groups. This is what makes discretion vulnerable to corruption or is considered to be corrupt because the public officials must initiate an authority not regulated in the law resulting in state losses (Natasasmita, 2011: 143).

Regarding the corruption cases in Indonesia, it can be further investigated that the corruption involving state officials is closely related to discretion. For example, the corruption case that happened to the former Governor of BI (Bank Indonesia) Burhanuddin Abdullah, former Chairman of the Indonesia Investment Coordinating Board (BKPM), Theo F Tuemion, former Minister of Maritime Affairs and Fisheries, Rokhmin Dahuri (Natasasmita, 2011: 145) or a case alleged to the former Minister of State-Owned Enterprises (SOE), Dahlan Iskan, suspected of committing a criminal act of corruption even though later declared free by the Supreme Court. 
The same thing happened at the local government level, where many heads of departments were sent into the jail for being alleged to have committed corruption over discretion. The impact was that many administrative officials were reluctant to do discretion and implement government projects. The steps taken by administrative officials by allowing the budget to be budget surplus (SiLPA) make the budget absorption not optimal.

Previous studies on discretion and corruption acts have been conducted by several authors, including, first, Benny Irawan (2011) stating that public officials were often accused of corruption because of their power of discretion even though the money or facilities obtained were not for personal interests and, second, Ratna Nurhayati and Seno Wibowo Gumbira (2017) who concluded that the government's action (bestuurshandeling) due to the power of discretion with no proven act of corruption could be subjected to administrative sanctions as a form of justice and based on casuistic, but if there were elements of corruption in the form of gratuities, collusion and personal-enrichment motives, the doer could be sentenced to criminal. Some previous studies on the relationship between discretion and corruption have not discussed the contribution of the Islamic law in the discretion problem above.

From this idea, this study was conducted to explore the study of discretion closely related to corruption by exploring the Islamic law as a solution to the problem. The Islamic law is dug up since it is one source of the material law in Indonesia. The values of the Islamic law have basically colored the conception of law in Indonesia. Islam underlays the basic general (universal) principles of law without being limited by space and time, which allow the formulation of a law for the people's welfare/ Religion is the foundation of human life while the rule of law and state administrators are its guardians (Engineer, 2000: 58). Mahfud MD (2007: 11) said that Indonesia is a religious nation state. Indonesia is not a religious state, but religious values enter and become the cornerstone of the state policy.

The problem formulation of this study is, first, how is the discretion scheme (Freis Ermessen) that has implications for criminal acts of corruption and, second, how is the contribution of the Islamic law in preventing discretion that has implications for criminal acts of corruption. This paper aims to find out the discretionary pattern or scheme that can have implications for criminal acts of corruption and the contribution of the Islamic law to avoid such the discretionary pattern. 
Contribution of islamic law in the discretionary scheme... (Muhammad Chairul Huda, Budi Ispriyarso)

\section{Research method}

The author used the normative juridical study method, where the law was seen as a normative tool with a library research approach. The study material was obtained from the secondary material taken from the literature review in the form of legislations, principles, theories, scientific works, books, holy books (turath) from the experts of both the general and Islamic laws, then analyzed with a qualitative approach. The results were presented with the analytical descriptive analysis technique.

\section{Discretionary scheme (freis ermessen) in government}

Discretion, which originates from an English word, is discretioner in French and freis ermessen in German (Atmosudirjo, 1994: 82). Literally, freis ermessen comes from freieies ermessen. Frei means free, independent, released, not bound. Freieies means people who are free, independent and not bound. Ermessen means to consider, estimate, suspect, and judge. Therefore, freis ermessen means people who have the freedom to make judgments, suspect and consider. This term is then typically used in government which is then interpreted by means that gives the authority to public officials or state administrative institutions to act without having to be fully bound to the rules of law (Sinamo, 2010: 62).

Freis ermessen is an inevitability in the concept of a welfare state, but in a state of law, freis ermessen is not unlimited. Freis ermessen is an alternative to fill the lack of wetmatigheid van bestuur (the principle of legality). The use of freis ermessen must remain within the corridors of the prevailing law. The implementation of freis ermessen must not be contrary to the law (positive law) and must be aimed at the public interest (Sinamo, 2010: 65).

In the implementation of governance, discretion (freis ermessen) is carried out by state administrative officials in the event that: (1) there is no regulation governing the settlement of a case in concreto even though the case requires a speedy resolution; (2) there is a regulation as the basis for granting full authority; and (3) there is a delegation i.e. the authority for self-regulation, which is actually the authority of the administrative officer above (Sinamo, 2010: 62). Alison Liebling (2000: 349) said that:

"The discretionary use of very high levels of power without recourse to a set of principles to guide its use leaves a wide legitimacy, deficit of a fairly precise kind. In one sense, what staff can distribute now 
is legitimacy. As some officers argued, if you fit into the 'compliant' troublesomeness category, then you deserve respect and but if not, then you do not".

Sjachran Basah (1992: 154) put forward the elements of fries ermessen as follows; (1) for the sake of carrying out public service tasks; (2) active actions in state administration; (3) made possible by law; (4) based on own initiative; (5) aimed at resolving important problems that arise suddenly; and (5) morally accountable to God Almighty. In the Law No.30 of 2014 Article 22 paragraphs 1 and 2 is explained that discretion can only be carried out by government officials who have the authority for the smooth administration in the government, filling the regulatory vacuum, providing legal certainty (the principle of legality) and providing solutions to deadlocks in government services.

The absence of legal basis/or rules as the basis for taking this discretion will certainly cause abuse in its implementation. This abuse can be done intentionally or not, which will eventually have implications for criminal acts. State administrative officials who carry out discretion must exercise prudence so as not to lead to corruption.

Erlyn Indarti (2010: 41) believes that discretion is an inevitable act for public officials and sometimes seems to contradict the existing rules. In discretionary decision making, the processes of prudence to be understood are (1) examining the problem faced, (2) reading the existing regulations, (3) interpreting the rules carefully, (4) choosing the rules as needed, (5) choosing and determining, (6) making legal decisions, and (7) taking certain legal actions.

In the study of State Administrative Law, the limitation of the authority of public officials in discretion is to pay attention to, first, the abuse of power/authority (detournement de povouir) and arbitrariness (abus de droit). Meanwhile, in the study of the criminal law, the element of abuse of power and wederechtelijkheid must be taken into consideration. In the study of the civil law, there are the terms wanprestasi and onrechmatigedaad (action against the law) (Natasasmita, 2011: 143-149).

Discretion in the level of the state administration law has values as the basis for its implementation. These values are stated in the general principles of good governance (AAUPB) contained in the article 10 of Law no. 30 of 2014. These principles are the basic reference in taking discretion carried out by the government because the society cannot be 
considered as an object in the state.

AAUPB stated in the act covers the principles of legal certainty, expediency, impartiality, accuracy, non-abuse of power, openness, public interest, good service and principles other than those which serve as the basis for judges in the judgments contained in the court decision with permanent legal force.

Discretion can also cause problems if it does not adhere to the principles above. The accountability for the problem that occurs in this discretion can be of a person or official. In the context of the position, there is no maladministration, but in the personal responsibility, there will be possible practices of maladministration which can then lead to criminal acts of corruption (Ansori, 2015: 134-150).

Table 1. scheme of discretion problem

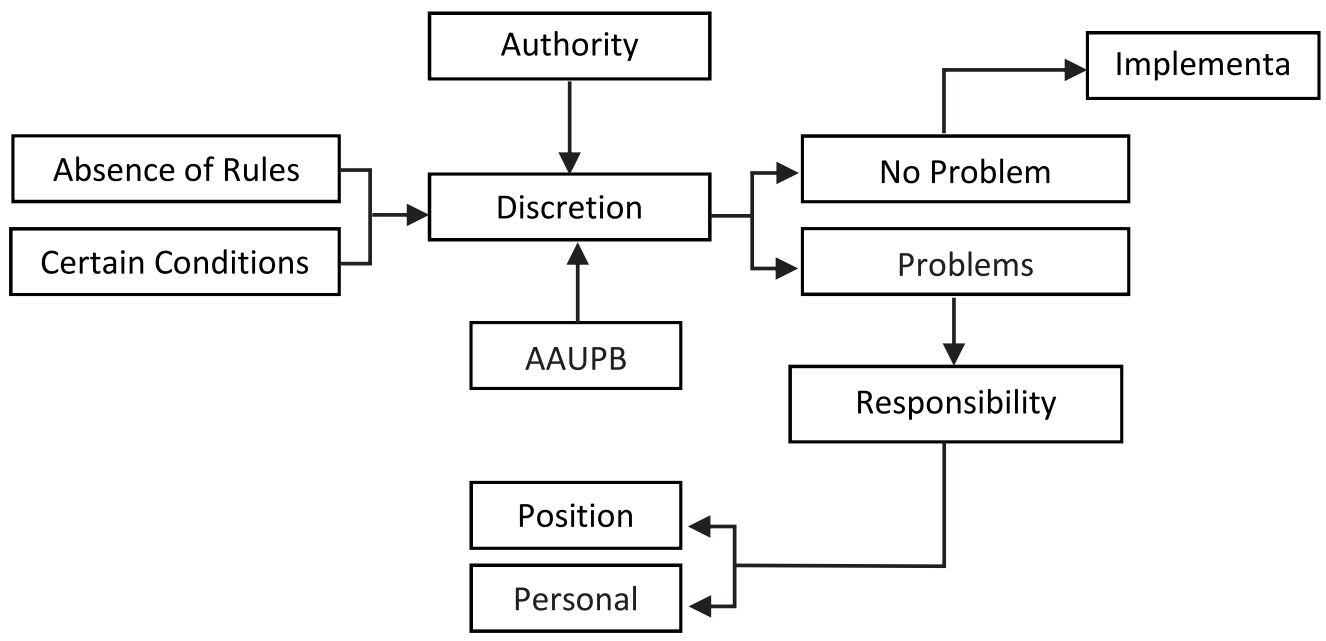

The table above illustrates the pattern of the discretion flow carried out by government officials. This pattern starts from the given authority based on the absence of certain rules and conditions due to the emergence of discretion. In the implementation of discretion, there are values in the general principles of good governance for the basis in taking discretion as the discretion is not problematic. If the discretion causes a problem, then it is of the personal responsibility, not of the position. 
The above scheme provides information to us that discretion in its implementation can cause problems if it is not in accordance with the values contained in AAUPB and the problem will have implications for personal responsibility, so if we want to construct preventative measures in discretion, we can start of these two, the basic value of discretion and personality.

This basic value as a reference in discretion and personality will be built based on the Islamic law as part of its contribution to discretion as the government's action so as not to deviate and fall into criminal acts, especially related to corruption.

\section{Corruption in discretion in the perspective of islamic law}

Corruption is a criminal act that is currently a common concern of the Indonesian nation. Various attempts have been made to reduce these actions both through repressive and even preventive actions. It turns out that these efforts have not been able to reduce the number. This can be seen from the data released by the Corruption Eradication Commission (KPK) that the number of corruption cases has increased over the years. In 2018, for example, there had been 113 cases that had been executed from 83 cases in 2017 and 81 cases in 2016. These are, of course, big corruption cases handled by KPK with the potential state loss of above 1 billion Rupiah. As of December 31, 2018, KPK handled corruption with the details of the inquiry of 164 cases, the investigation of 199 cases, prosecution of 151 cases, inkracht of 106 cases, and execution of113 cases (Kpk.go.id)

Corruption is a real act of deviation from the law and social norms in the life of the nation and state with the clear sanctions in accordance with applicable laws. Even, corruption is categorized as an extraordinary crime, besides terrorism and drugs.

According to Adami Chazawi (2005: 1), the word corruption originates from English, which is then absorbed in Indonesian. Referring to its origin, corruption means to damage. Some say that corruption originates from Latin, corruptus or corruption. Corruptus originates from the word corrumpere, which consists of com (comprehensive) and rumpere (damage), whereas in the Dutch Dictionary is known corruptie, which means truly damaging (Adami, 2005: 1). In the Big Indonesian Dictionary is stated that corruption is a criminal act of embezzlement and misappropriation of the state or company fund for personal gain 
(Perwadarminta, 2001: 462). Corruption can also mean destruction, badness, deception, bribery, immorality, deviating from purity, speaking with slander or insulting (Satria, 2017: 88). Besides, corruption is also interpreted as an act of zalim, which is contrary to 'adl or justice (Mudofir, 2019: 19). According to the Law No. 31 of 1999, it is stated that the criminal act of corruption is any person who violates the law by enriching him/herself or someone else or a corporation that results in detrimental to the country and its economy. According to Barda Nawawi Arif (2014: 15), corruption is also categorized as a crime as business, organized crime, and white collar crime. Corruption can be interpreted as one's behavior of using his authority and position for the his/her own benefit or others' resulting in the loss of the interests of the people and the state. The concrete forms of corruption practices can be embezzlement, bribery, subornation, manipulation and so on.

The treasure of Islamic legal concept (figh) does not mention clearly in the nash of both the Qur'an and the Sunnah about the behavior of criminal acts of corruption, but there are several terms used to qiyas with corruption, namely gasab, sāriqah, gulul, khianat, hirabah, risywah (Al Bajuri, n.d: 16). The first is gasab, which means taking something that does not belong to the taker wrongfully. Gasab is taking or controlling the property of others without their permission, sometimes done openly or by force. The second is säriqah, which is taking the property of others surreptitiously. The third is gulul, which literally means treasonous, which is renegading the assets entrusted to be managed properly and wisely. The fourth is khianat, which means someone who is given the authority to take care of something in the form of money or goods. Most of the Syafiiyah scholars classify corruption in the treasonous crime is the traitors are those given the trust to manage state assets (Jumali, 2014: 115116). The fifth is hirabah, which is the action of a person or more in a country to disrupt the state security, commit murder, hijack, robbery and so forth. Hirabah can cause death or disruption of order and security. The sixth is risywah, a bribe given by a person to an official or law enforcer to act according to the wishes of the briber (Jumali, 2014: 116). Of the six Jarimah classifications mentioned above, those closer to the nature of corruption are gulul, khianat and risywah.

In the study of fiqh jinayah (Islamic criminal law), there are three kinds of violations of the law (jarimah), namely budud, qișạs / diat and ta'zir. ta'zir. Hudud is a violation or crime, the 
type and the threat of punishment of which have been stated in the nash or had punishment (the right of Allah). There are seven categories of budud, namely adultery, accusing others of adultery (qadhaf), stealing (säriqah), robbing (ḩirabah), drinking alcoholic beverages (syurbah) and apostasy (riddah) (Audah, n.d: 78-81).

Jarimah qisạs /diyat is an act of violation that is punishable by qișạs/diyat, which is a punishment with neither low nor high limitations, but it is the personal authority of both the victim and his/her guardian. Qișass can turn into diyat while diyat can be abolished if the victim or the guardian has forgiven the doer. Diyat can be abolished if there is forgiveness from the victim or the guardian of the victim. The categories of jarimah are intentional homicide (qatl 'amd), unintentional homicide (qatl syibh al-'amd), erroneous homicide (qatl alkhata), deliberate persecution (jar-al-'amd) and erroneous persecution (jarh khata) (Audah, n.d: 81$)$.

Jarimah ta'zir is a crime whose sanctioning authority is on the leader/ruler/ judge for public benefit. The most important principle of the application of ta'zir is to maintain public order and prevent harm (danger) in the community. However, jarimah ta' żir must still refer to sharia principles. The examples of Jarimah Ta'zir are traffic violations, exploitation of natural resources and the environment and so forth (Audah, n.d: 82). Violations of discretion, which cause state losses and harm the people both detournement de povouir and abus de droit, can be categorized as jarimah ta'zir. The judges or officials above have the authority in giving sanctions on Jarimah Ta'zir. They are authorized to pass verdicts based on the prevailing laws and regulations in the country.

Islam as a kaffah (comprehensive) religion provides dogmatic to its followers in the creation of an orderly and well-organized society according to the applicable law. The modern legal philosopher, Rescoe Pound (2017: 21) said, "Law as an instrument of social engineering", which means that the law serves as a means of control in society. Islam also directs its followers through its laws as a means of control and social engineering towards civilization and improvement in the structure of society. The Islamic law also contains the teachings for preventive endeavors of corruption and other criminal acts (jinayah) in social construction.

The explanation above related to criminal acts of corruption as a result of deviations from the discretion in view of the Islamic law is expected to be able to explain that the 
Islamic law can make a contribution related to the implications of discretion. If at the level of implementation, the Islamic law can contribute, then in the discretion scheme that has been explained above, it can also contribute to the problems that will make this discretion cause problems related to criminal acts related to the basic values and personality in the discretion scheme.

\section{Contribution of islamic law in discretion}

As put forward by Mahfud MD, as a Religious Nation State, Indonesia can absorb religious values to be the basis for the state policy. The nature of the Islamic law that is rabmatan lil alamin also makes the Islamic law more flexible to enter the conventional legal scheme to bridge the gap created at the level of sein and sollen.

In the discretion scheme, the problems that need to be considered and that could raise other problems are regarding the reference of basic values and personality. The reference value as a basis for discretion so as not to deviate has actually been mentioned in the Law No. 30 of 2014 concerning government administration. However, if we look at the values contained in the Act, it has not yet been explained rigidly the form of the values contained therein, for example the principle of impartiality. The implementation in discretion of this principle of impartiality is not further explained, so the reference values that exist cannot be understood in the policy making process. Therefore, the contribution of the Islamic law in discretion in the context of values is very important because there is a further explanation of the values in making policy.

The basic reference of values contained in the Islamic law related to discretion is the benefit of the followers. This discretion (freis ermessen) must be carried out within the corridor of the benefit of the followers. The concept of the benefit of the followers refers to almaqassid al-syariah, which is the development of the spirit and values of the Islamic law in various dimensions of community life (Fathony, 2018: 270). The conception of the benefit in Islam is divided into three maslahah. In this context, it is understood as the fulfillment of the enjoyment and happiness of humanity based on legal norms that contain physiological aspects (physical), psychological and ethical happiness. Maslahah, which is projected by the Islamic law, combines the physical and spiritual elements in human beings (Huda, 2016: 134). 
Ijtihad: Jurnal Wacana Hukum Islam dan Kemanusiaan, Volume 19, No. 2, Desember 2019: 147-167

According to Abdul Karim Zaidan (1990: 379-382), Maslạ̣ah is classified into three, namely: The first is maslaḥah daruriyyah, the principle of benefit for the sake of maintaining human life and the existence of society. Human life will be damaged/lost if this principle is lost. Maslahah daruriyyah is the basic rights (primary) that must be granted by the government to its people, which include five aspects of hifd al-din (protecting the religion), hifd al-nafs (protecting the soul), hifd al-'aql (protecting the reason), hifd al-nasl/ hifd al-nasb (protecting the heredity), and bifd al-nasl (protecting the property).

If the reference of values above is contextualized in government discretion and administration, hifd al-din is the role of the state or state administrative officials to provide protection to their people in performing worship freely according to their respective beliefs without coercion and intimidation as stated in the Q.S. Yunus verse 99; "And if your Lord had willed, surely all those who are in the earth would have believed altogether. Will you then force men till they become believers?" Hịfd al-nafs (protecting the soul), in this aspect, the government must provide a sense of security from any disruption that can threaten, injure or kill the lives/ bodies of its people. Q.S. Al-An'am verse 151 explains: "Do not kill which Allah has forbidden except for a just cause."

The aspect of hifd al-'aql (guarding reason) in the context of the government discretion and administration is that the function of government is to provide protection to its people to develop their potential and knowledge according to hadith of the Prophet Muhammad; "Studying is the duty of every believer." Meanwhile, hifd al-nasl/ hifd al-nasb is a form of government obligation to provide facilities to the people who are engaged in marriage in order to protect their heredity and family formation. Allah Almighty commands to conduct marriages according to Sharia and forbids the act of adultery according to what is stated in Q.S Al-Isra verse 32; "Do not approach adultery! Surely it is an indecency and evil way."

The aspect of hifd al-māl (protecting the property) is the role of the government in providing security for the property of its people from acts of plunder, looting, robbery, theft and so on. Also, the function of the government is to regulate the trade and economy of the community in order to create an economic system that provides a welfare impact (welfare state). This is in accordance with Q.S. Al-Jumu'ah verse 10; "Now when you are done with the prayer, disperse in the land and seek of Allab's Virtue, and remember Allah much (repeat the 
Contribution of islamic law in the discretionary scheme... (Muhammad Chairul Huda, Budi Ispriyarso)

\section{Name of Allah much). It is hoped that you may have Salvation."}

The second is maslahah hajizyah, which is a policy (benefit) that is needed by the people to eliminate the difficulties of life. The unfulfillment of maslaḥah hajïyah will not cause damage to the five aspects above, but will only make the people get insignificant difficulties of life.

The third is maslahah taḅnisiyah, which is the benefit in the perfection of life. It is a tertiary need, which is a complement or possession of luxury goods.

This conception in al-maqāsid al-syariah is in line with the state's goals contained in the 1945 Constitution, namely, first, protecting all elements of the nation for the integrity of the nation; second, realizing social justice; third, realizing people's sovereignty (democracy) and the rule of law (nomocracy); and fourth, creating tolerance on the basis of humanity and civilization in religious life (Mahfud MD, 2017: 18). Discretion carried out by the public policy must not come from the concept of al-maqāsid al-syariah nor the purpose of the state formation. Discretion must really be placed on the portion as a bridge to the void of regulation in the frame of the welfare and well-being of society in general. Furthermore, if the state administrative officials must choose and decide on discretion, it can be grounded in the following qawaid al-fiqhiyyah guidelines;

First, the duties and responsibilities of a leader are tașaruf al-imàm alà ra'iyyah manütun bi al-maslạah, which means that the actions and policies of a leader over the people are based on their benefit. Imam Shafi'i explains that the position of the head of state over his/ her people is like a guardian to the orphans they care for (Mudjib, 2001: 61). This fiqhiyyah principle is based on Caliph Umar bin Khattab who said that;

"T put myself in terms of the treasure of God in the position of guardian of the orphans. If I need it, I will take it and if I can, I will return it. If I feel enough, I will protect myself from it" (Mudjib, 2001: 62).

Jalaludin Abdurrahman As-Suyuti in the book of al-Asybah wa an-Nadha'ir explains that the fiqhiyyah principles are in harmony with the context of a head of state who is given the authority to choose policies regarding the punishment for the prisoners of war, between punishing with qisās, being slaves, being freed unconditionally and being freed by ransom . A head of state or government may not choose to decide based on his/her anger, but the benefits that will be incurred. Therefore, if, apparently, there is no benefit, it is better 
to hold the prisoner until there is the benefit (Asy Suyuti, 1995: Maktabah Samilah Ed.2).

The second is al-dararu yuzalu lakin la bidarari, which means that the danger must be eliminated, not by making another danger. Jalaludin Abdurrahman explains in relation to this principle that it is like a person who is in a food emergency. He/she cannot eat the food of other people with the same conditions. If interpreted freely in the context of state life, then under no circumstances would looting, corruption or taking the property of others be permitted (Asy Suyuti, 1995). This principle gives a birth to a new rule "idha ta'a radh al-mafsadatani ruwiya a'zomubuma darara al bar takäbi akhfibima" that is if there is a conflict between the two damages, then note which damage is greater than another by doing the lightest of the two (Asy Suyuti, 1995).

The third is Idha al-ajtama'a al-daruri fäilaikum biakhaifibima, which is if there come two dangers together, then take a lighter one. In the book of al-Faraidul Babiyyah (translated by Adib Bisri), it is likened to an ill patient who is recommended by a doctor to do a surgical operation which actually contains an element of danger (daruri). The patient is faced with the choice of performing surgery or suffering from the disease permanently, so the permanent disease is more dangerous than surgery. Therefore, based on this principle, the patient chooses to perform surgery (Bisri, 1977: 24).

The fourth is al-ta'sisu al-ula min al-ta'kidi, which means that basing is more important than determining. In the context of HAN, this principle can be interpreted that the actions of administrative officials are based more on the laws and regulations or on the orders of superiors rather than establishing and producing policies. The fifth is al-ridha bi al-syai'i ridho bima yatawalladu minhu, which means that willing to something means willing to what arises from it (As-Syafi'i, 1412: 23-49). Discretion certainly has an impact that must be realized by administrative officials along with all its consequences.

Referring to the qawaid al-fiqhiyyah, public policy makers can use it as a reference value in the application of discretion. The reference values contained in the Islamic law above are certainly different from the concept of values in AAUPB which do not have interpretation on a practical level. With this concept, it is expected that policy makers or officials who have discretionary authority can more easily make values as a basis for implementing discretion so as not to have implications for corruption. 
The contribution of the Islamic law in the second discretion scheme is the problem of personality. Personality basically touches all aspects of human life. The most basic improvement in everything should be done through individual improvement. At the public level, the concept of personality is considered a private area that cannot be reached by the state, but this is different in the context of the Islamic law.

In Islam, personality as a concept of leadership is reflected in the four characters of the Prophet, namely siddiq (honest), 'amanah (accountable), tabliq (conveying), and fatanah (intelligent, sensitive). These four characters must be emulated by every adherent of Islam in making individual improvement. Individual improvements are made to ensure that the discretion carried out by officials does not lead to this criminal act of corruption by emulating the four characters as well as implementing several things individually as an official.

The first is the uswah (pattern) and consistency of a leader. The uswab of a leader, in the context of abuse of power, are a leader who has the vision, commitment and integrity to always prioritize the interests of the people above the interests of individuals, families and groups. The leader must be oriented towards the good for the benefit of the people.

Lately, the Indonesian nation has experienced an uswah crisis from its leaders. This can be seen from the many officials, from ministers or former ministers, legislatives, regents, heads of regions, to judges who have been convicted of abusing their power. These legal cases make the image of this country's leaders bad in the eyes of the people. The officials who once promised in the campaign to defend the interests of the people turn out to be inconsistent by heartlessly seizing people's rights.

The Islamic history teaches that the missionary endeavor carried out by the Prophet Muhammad was the most successful in the history of mankind. Michael H Hart (2001: 1-4) in the book 100 Tokoh Paling Berpengaruh (100 Most Influential Figures) put Muhammad as the number one. If you reflect on the missionary endeavor carried out by Muhammad SAW, then you will find the key to his success, namely istiqamah (consistency) and uswah hasanah (good pattern) (Syamsudin, 2014: 798). Muhammad SAW is always consistent in his missionary endeavor despite various challenges, insults, temptations that accompany. Neither physical, psychological, exile nor other threats hamper the mission his missionary 
endeavor. Muhammad SAW also became uswah (pattern) for his friends and followers. This is a characteristic of the transformational leadership model (Allolangi, 2014: 151-169) or charisma, according to Max Weber (1968: 263). Muhammad SAW teaches what he practices. If Muhammad forbids to abuse power, he will not do it. Q.S. Al-Ahzab verse 21 reads: "There has certainly been for you in the Messenger of Allah an excellent pattern for anyone whose hope is in Allah."

The pattern of Islamic leadership found in Muhammad SAW is an inspiration for public officials at any level, being a role model and consistent not to abuse power in discretion. In the Islamic perspective, the main duty of a leader is riayatud dien (protecting the religion) and ri'ayatud daulah (protecting the country and developing people's welfare) (Budiharto \& Himam, 2006: 138).

Both duties are based on the vision of Islam as rabmatan lil 'alamin, which provides the maximum benefit to the universe, rather than destroying it with acts of corruption. In Q.S. AnNisa verse 59, Allah commands: "O you who have believed, obey Allah and obey the Messenger and those in authority (ulil 'amri) among you." From this verse, it can be interpreted that we must obey the good leader (ulil 'amri), a leader who continues the prophetic treatise, which does not contradict the teachings of Allah and His Prophet and the leader who deserves to be set as the role model for the community. The exemplary of national leaders in preventing corruption is a must for the people's welfare. The character of the nation will be determined by its leaders. The destruction of a nation is caused by the destruction of its people and the destruction of the people is caused by the destruction of their leaders. The ideal relationship pattern is a leader who acts fairly to the people and the people who obey their leader (Anshori, 2016: 187).

The second is muraqabah, which is the belief that must be possessed by every human being in order to keep their morals. The essence of muraqabab is to instill a feeling that all the behavior that we do is always seen and monitored by Allah SWT.

Muraqabahis an attitude of feeling the presence of Allah that is very close (Khalilurrahman, 2013: 5). The closeness of Allah Almighty to His servants is explained in Q.S. Qaaf verse 16; "I (Allah) are nearer to my servants compared to their jugular veins." We must be accounted for anything we do in the hereafter. Q.S. Al-Zalzalah verse 8 explains: "And whoever does an atom's weight of evil shall see it." The Hadith of the Prophet says, "Everyone is a leader and 
will be accounted for his leadership" (Hadith of Bukhari and Muslim). With the feeling of being watched over by Allah SWT, everyone will be careful in doing anything. The phrase Subhanahu wata'ala (usually abbreviated as "SWT"), which is often juxtaposed with the name of Allah, means that Allah is the Most Holy and Omniscient of everything that is done by each of His servants.

If muraqabab is attached to a person, he will undoubtedly stay away from unlawful acts and corrupt behavior that harms others. The substance of human creation in this world is nothing but to worship Allah SWT as the word of Allah SWT in Q.S. At-Thuur verse 56; "And I (Allah) created not the jinns and humans except they should worship Me (Alone)."

The third is Qana'ah, an attitude that accepts and feels enough for the fortune given by Allah (Arifin \& Said, 1981: 14). The opposite of the word qana'ab is greedy. According to Abraham Samad (Marwan, 2014: v), the abuse of power is a deviant behavior that is driven by material insatience or the greed that exists in humans. It is true that one of the indicators of welfare is the material fulfillment in the form of property, but it is only a manifestation of fulfilling human needs as abdullah and khalifatullah fil ardi.

Islam teaches its followers to be balanced in treating the property, and not live in luxury. Islam also prohibits from lazing in earning a living. Muslims are demanded to be professional and diligent in working and not to leave their children in a weak condition (Q.S. An-Nisa 'verse 9) and not to pile up assets that are not distributed for public benefit. It is emphasized that we earn living with the blessed and halal manners, not with syubhat, haram, or corrupt manners. Al Mawardi said that the jahiliyah community (the ignorance) in the past competed for material luxuries, put forward their bubbuddi as prestige, while the muttaqin were taught to compete in piety and faith because greed and luxury led to arrogance, and arrogance would neglect human identity (Mawardi \& Habib, 1982: 192). Allah SWT confirms in Q.S. At-Takatsur verse 1; "Competition in [worldly] increase diverts you."

Quraish Shihab said that the lives in the world and in the hereafter are a unity. There is no classification of the deeds in the world and in the hereafter. It is important to place the afterlife as the main target while the world as wasilab (medium). We must be serious and work hard in reaching happiness in afterlife and must not be too much in worldly happiness (extravagance) (Shihab, 2006: 506). 
The fourth is protecting ourselves and our families. The family is the smallest unit in the social order. It is an institution formed by the bond of marriage between husband and wife. The purpose of marriage is to form a sakinah, mawadah, and warạ̣mah family. (Law No.1 of 1974). Q.S. Al-Tahrim verse 6 commands that you protect oneself and his family from bad things. One can protect his family by cleaning the living from something that is haram (Q.S. Al-Baqarah 215), including that from corruption. Q.S. Al-Maidah verse 88 reads, "And eat of what Allah has provided for you [which is] lawful and good. And fear Allah, in whom you are believers." A good living (halal) for the family will make good behavior. On the contrary, the haram living will make bad behavior. The attitude of a Muslim is to take the halal and stay away from the haram and refrain from something that is syubhat until the law is known (Zulaekah, 2005: 27). Therefore, the living for oneself and his family must be a halal living as an effort to keep away from hellfire. It is from the family that the next generation will be created. Good families and children in a good family will give birth to a pious generation. It is hoped that a pious family will create a pious generation for the realization of a prosperous country as aspired in the 1945 Constitution.

\section{Conclusion}

Based on the explanation above, it can be summed up that discretion is an act that can have implications for corruption. In the discretion scheme, there are several reasons why discretion exists including the existence of authority, the absence of governing laws and certain conditions. Meanwhile, the basic reference in discretion is the general principles of good governance (AAUPB). Discretion will be problematic if carried out without the foundation of the AAUPB that requires personal responsibility. Therefore, there are two crucial things to be addressed regarding the implementation of discretion, namely the basic values and personality problems.

Problems with basic values and personality can be resolved by analyzing the Islamic law as part of its contribution to the problem of discretion that results in criminal acts of corruption. Basic values in Islam rely on the benefit of the followers by referring to the principles of ushul contained in the Islamic legal literature for the good implementation in the practical level. The personality problems are resolved by obliging officials to perform 
Contribution of islamic law in the discretionary scheme... (Muhammad Chairul Huda, Budi Ispriyarso)

exemplary attitude, muroqobah, qona'ah and take care of themselves and their families from bad things. The contribution of the Islamic law in the basic values and personality is a preventive effort so that the implementation of discretion does not lead to corruption.

\section{Reference}

Adami, C. Hukum Pidana Materiil dan Formil Korupsi di Indonesia. Malang: CV. Bayu Media. 2005.

Allolangi, Y. R. Kepemimpinan Transformasional sebagai Kepemimpinan Dakwah. Jurnal Ilmu Dakwah, 6 (1), 2014. https://doi.org/10.15575/jid.v6i1.331

Anshori, A. Konsep Siyasah dalam Yahudi dan Islam. Asy-Syir'ah: Jurnal Ilmu Syariah dan Hukum, 6(1), 2016. Retrieved from http://www.asy-syirah.uin-suka.com/index.php/ AS/article/view/169

Ansori, L. Diskresi dan Pertanggungjawaban Pemerintah dalam Penyelenggaraan Pemerintahan. Jurnal Yuridis, 2 (1), 2015. Retrieved from https:/ / ejournal.upnvj.ac.id/ index.php/Yuridis/article/download/165/137

Arif, B. N. Bunga Rampai Kebijakan Hukum Pidana (7th ed.). Jakarta: Kencana. 2014.

Arifin, B., \& Said, A. Rahasia Ketahanan Mental dan Bina Mental dalam Islam. Surabaya: AlIkhlas. 1981.

Atmosudirjo, S. P. Hukum Administrasi Negara (Cet. 10). Jakarta: Ghalia Indonesia. 1994.

Audah, A. al-Q. (n.d.). al-Tasyri al-Jinai al-Islami Muqorinnan bi al-Qanun al-Wad'i (2nd ed.). Beirut: Darul Kitab al-Arabi.

Basah, S. Perlindungan bukum terhadap sikap-tindak administrasi negara. Bandung: Alumni. 1992. Al-Bajuri, I. (n.d.). Hasyah Syeh Ibrohim al-Bajuri (Juz 2). Beirut: Darul Fiqr. t.th.

Bisri, M. A. Terjemahan al Faraidul Babiyyah. Kudus: Menara Kudus. 1977.

Budiharto, S., \& Himam, F. Konstruk Teoritis dan Pengukuran Kepemimpinan Profetik. Jurnal Psikologi (Yogyakarta), 33 (2), 2006. https://doi.org/10.22146/jpsi.7081

Engineer, A. A. Devolusi Negara Islam. Yogyakarta: Pustaka Pelajar. 2000.

Fathony, A. Maqashid al-Syariah Sebagai Konsep Dasar dalam Teori Pembentukan Hukum Islam di Indonesia. Jurnal Islam Nusantara, 2(2), 2018. https://doi.org/10.33852/ jurnalin.v2i2.103 
Ijtihad: Jurnal Wacana Hukum Islam dan Kemanusiaan, Volume 19, No. 2, Desember 2019: 147-167

Githa Angela Sitohang. Tugas dalam Situasi Darurat. Diskresi dan Tanggung Jawab Pejabat Publik pada Pelaksanaan Tugas dalam Situasi Darurat, 13(1), 2017.

Hart, M. H. Seratus Tokoh yang Paling Berpengaruh dalam Sejarah. https:/ /doi.org/5432gf.2001. Huda, N. Studi Fatwa Majelis Tarjih Tentang Merokok. al-Tuhfah, 5(9), 2016.

Indarti, E. Diskresi dan Paradigma. Pidato Guru Besar. November 2010.

Jumali, E. Penerapan Sanksi Pidana Ta'zîr bagi Pelaku Tindak Pidana Korupsi di Indonesia. Asy-Syariah, 16(2). 2014. https://doi.org/10.15575/as.v16i2.631.

Khalilurrahman. Konsep Implementasi Dimensi Afektif-Spiritual bagi Auditor dan Aparatur. Jurnal Fokus Pengawasan, 10 (3). 2013.

Kpk.go.id. (n.d.). tindak pidana korupsi.

Liebling, A, P. officers. policing and the use of discretion. Theoretical Criminology, 4(3), 2000. Mahfud, M. Politik. Hukum dalam Perda Berbasis Syariah. 14(1), 2007.

Mahfud MD, M. Membangun Politik. Hukum Menegakekan Konstitusi. Jakarta: Rajawali Press. 2017.

Marwan, M. Pemberantasan Tindak Pidana Korupsi. Bogor: Ghalia Indonesia. 2014.

Mawardi, A., \& Habib, A. bin. An-Nukat Wal Uyun (4th ed.). Kuwait: Wizarat al-auqaf wa as-syu'un al-Islamiyah. 1982.

Mudjib, H. A. Kaidah kaidah ilmu fiqih:(al-Qowa'idul Fiqhiyyah). Kalam Mulia. 2001.

Mudofir. Menegaskan Fikih Anti-Korupsi untuk Pembangunan Bangsa : Perspektif Filsafat Hukum Islam. Ejournal.Fiaiunisi, 6 (1)., 2019.

Natasasmita, B. I. Diskresi sebagai Tindak Pidana Korupsi: Kajian Kriminologi dan Hukum terhadap Fenomena Pejabat Otoritas. MIMBAR, Jurnal Sosial Dan Pembangunan, 27(2), 2011.

Nurhayati, R., \& Gumbira, S. W. Pertanggungjawaban Publik dan Tindak Pidana Korupsi Responsibility Public Officials and Corruption. Jurnal Hukum dan Peradilan, 6, 2017.

Perwadarminta, W. J. Kamus Besar Bahasa Indonesia. Jakarta: Balai Pustaka. 2001.

Pound, R. Social control through law (3rd ed.). New York: Routledge. 2017.

Rahardjo, S. Penegakan Hukum Progresif. Jakarta: Kompas. 2010.

Satria, H. Ke Arah Pergeseran Beban Pembuktian. Integritas: Jurnal Antikorupsi Komisi Pemberantasan Korupsi, Vol.3 No.1.2017. 
Contribution of islamic law in the discretionary scheme... (Muhammad Chairul Huda, Budi Ispriyarso)

Shihab, Q. Tafsir al-Misbah (1st ed.). Jakarta: Lentera Hati. 2006.

Sinamo, N. Hukum Administrasi Negara: Suatu Kajian Kritis tentang Birokrasi Negara. Jakarta: Jala Permata Aksara. 2010.

Subhi, M. Falsafah al-Tasyri' fí al-Islam, Dar al-Tlm li al-Malayin (V). Lebanon: Beirut. 1981.

Al-Suyuti, J. A. al-Asybah wa Nadhoir al-Asybah wa Nadhoir. Beirut: Darul Fikr. 1995.

Al-Syafi'i, A. sayid A. B. al A. A. Y. Al Faraidul Bahiyyah fil qowaidil fiqhi. Ploso, Kediri: Al Ma'had wal Madrasah Al Islamiyah Assalafi. 1412.

Syamsudin, R. Strategi dan Etika Dakwah Rasulullah SAW. Ilmu Dakwah: Academic Journal for Homiletic, 4 (14), 2014. https:/ / doi.org/10.15575/idajhs.v4i14.422

Weber, M. On charisma and institution building. University of Chicago Press. 1968.

Zaidan, A. K. Al-Wajiz fi ushul fiqh. Beirut. 1990.

Zulaekah, S., Yuli Kusumawati, Ilmu, F., Universitas, K., \& Surakarta, M. Halal dan Haram Makanan dalam Islam. Subuf, XVII(1), 2005. 
